\title{
Organic Farming in Jammu Region of J\&K State, India
}

\author{
Shahid Ahamad* and Banarsi Lal \\ Krishi Vigyan Kendra, Sher-e-Kashmir University of Agricultural Sciences and Technology of Jammu (J\&K), India
}

*Corresponding author: Shahid Ahamad, Directorate of Research, SKUAST Jammu, Jammu, J\&K, India

\section{Agriculture in J\&K}

Jammu and Kashmir is a mountainous state in which about 30 per cent of the area is under cultivation. Agriculture is the backbone of the state and this sector provides employment directly or indirectly to around 70 per cent of the state population. The agrodiversity of the state varies from sub-tropical in Jammu region, temperate in Kashmir region and cold arid in Ladakh region. Organic agriculture is generally environment friendly which maintains soil health and enhances biodiversity. Already large numbers of farmers of the state are growing vegetables, spices, basmati rice, walnuts, herbs etc. organically. There is need to introduce organic farming commercially, scientifically and in a systematized way so that the farmers can get rich dividends and farming can become sustainable.

\section{Potential of Organic Farming in J\&K}

J\&K has huge potential for organic farming as the large area in the state is already under semi-organic cultivation in hilly districts of the state due to the lack of availability of chemical Agro-inputs in these areas and the farmers of these areas avoid to apply the chemical Agro-inputs. Basmati rice of R. S. Pura, rajmash of Bhaderwah, potato of Gurez and Machil and red rice of Tangdar, Kupwara, vegetables, ginger and turmeric of Talwara, Reasi are major exportable organic products in the state and have the potential to fetch more returns in the market. Organic farming system is not new in the state and it is being followed from ancient times. There is need to provide logistic support for organic farming to the farmers so that they can get maximum benefits from it.

\section{KVK, Reasi Interventions}

\section{Organic Village Talwara of Reasi Distt. of J\&K}

Talwara village is around $6 \mathrm{~km}$ away from Reasi town of Jammu and Kashmir. Baseline survey of village Talwara was done by the KVK experts and it was found that the farmers of the village were interested in the organic farming especially vegetables and spices. Krishi Vigyan Kendra (KVK), Reasi scientists repeatedly approached to the farmers of this village and motivated them for the organic farming. The KVK scientists frequently visited the village and trained the farmers for the organic farming emphasizing on organic vegetables growing. The farmers 'clubs'/SHG formation was initiated in the village with the co-ordination of NABARD \&ACTECK. The KVK efforts were synergized by the Department of Agriculture and other line departments of the district including NGO. The farmers' clubs were encouraged for the organic vegetables growing in the village. In the beginning the farmers were advised to avoid the Agro-chemicals in the vegetables so that that the can be organically grown. The farmers were guided for the establishment of vermicompost units in the village so that the soil nutrients requirements can be fulfilled. In the beginning the farmers faced lot of problems as they were not getting the desired yields of the vegetables. The management of insect-pests and plant diseases was done by using the organic inputs. The quality vegetables seeds and other organic inputs were provided to the farmers. KVK, Reasi expertise were utilized by ACTECH and Department of Agriculture in creating awareness on certification process and other technical guidelines on commercial organic farming. After a long practice on organic farming the certification of their products was done by the Inter tech India Ltd. through Agricultural and Processed Food Products Export Development Authority (APEDA). Now the farmers of the village are selling the organic vegetables at the large scale. Their organic vegetables are sold in the local market and in Jammu at a good price. There are 8 farmers' clubs and oneself Help Group (SHG) of women who are working for the organic vegetables production. KVK, Reasi has also established an Integrated Farming System (IFS) model in the village which attracts the other farmers of the area for the IFS system. This IFS model is producing the organic crops and also has a high-tech dairy farm. By this entrepreneurship the farmers of this village generate extra income which develops the confidence among them and gain reconisation in the state. 


\section{Establishment of Organic Training Centre at Talwara}

Sher-e-Kashmir University of Agricultural Sciences and Technology of Jammu (SKUAST-J) has established an Organic Training Centre at Talwara village of Reasi district which is being sponsored by the Indian Council of Agricultural Research (ICAR), New Delhi under Pt. Deen Dayal Upadhaya Unnat Krishi Shiksha Yojana. Krishi Vigyan Kendra (KVK), Reasi is supervising the centre and upgrading the skill development of farmers especially on organic farming.

\section{Impact of KVK Activities}

KVK Reasi imparted the awareness/ trainings programmes/ kisan ghosties on organic farming in the village Talwara of Reasi distt. Till date by KVK experts have trained more than 500 participants on organic farming in Reasi district. Before KVK interventions farmers of Talwara village were using their traditional technologies for vegetables growing and they were earning only Rs.73,000/ha of vegetables but with the new scientific technologies of organic vegetables growing they raised their annual income upto Rs. 2, $55,000 /$ ha in 2014-15 to Rs.2, 87,100/ha in 2017-18. By growing the organic vegetables, the farmers are fetching more prices. By observing the successful results of organic vegetables growers in Talwara village, the other farmers of the adjoining villages such as
Kansi Patta, Kans Brahamna, Seela, Chaiter etc. are also showing keen interest for organic vegetables growing in the district. With the awareness on poly house technique of vegetables growing, the farmers are able to generate extra income by growing the vegetables seedlings in time. With the establishment of vermicompost units in the village, the farmers are able to fulfil the need of the required soil nutrients in the vegetables growing. With the generation of extra income organic vegetables growers developed confidence to mitigate their basic needs. A self- reliance and entrepreneurial spirit have been developed among the organic vegetable's growers in the village. Their new attitude for organic farming has been developed. With the increase in the income of the organic vegetables growers their respect and reconisation have also been increased not only in the village but also in the state. They exhibit their organic farm produce in different farmers' fairs organized by SKUAST-J\& allied departments and recognised by the different organizations. Their efforts for organic farming were highly appreciated by Hon'ble exDG, ICAR, Dr. S Ayappan, Hon'ble Union Minister Dr. Jatinder Singh, and Hon'ble J\&K Min. Sh. Ajay Nanda during their visit at KVK, Reasi. Hon'ble Vice Chancellor of SKUAST-J, Dr. PK Sharma also visited this village three times and appreciated the farmers for their efforts towards organic farming. KVK, Reasi is making strenuous efforts for the farmers' welfare through organic farming in the hilly district Reasi of Jammu and Kashmir (Figures 1-5).

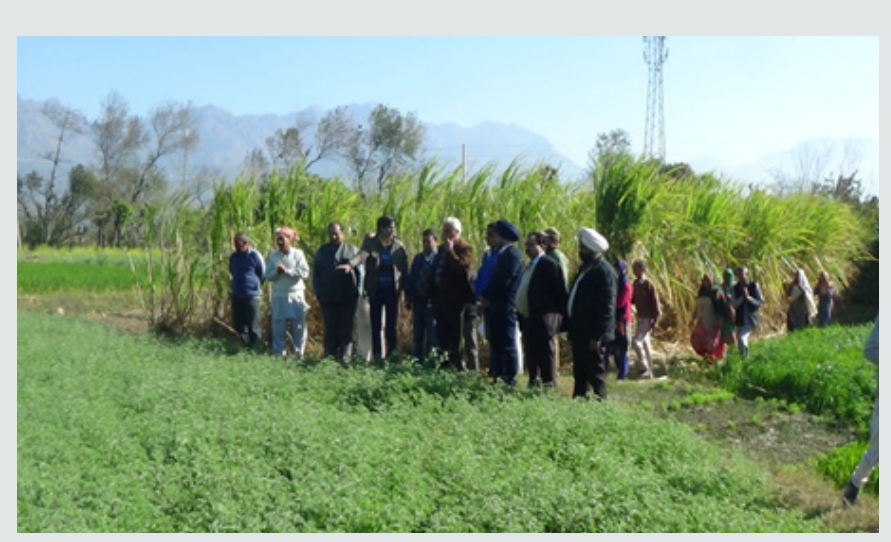

Figure 1: Hon'ble Vice Chancellor of SKUAST-J visit at Organic Village Talwara

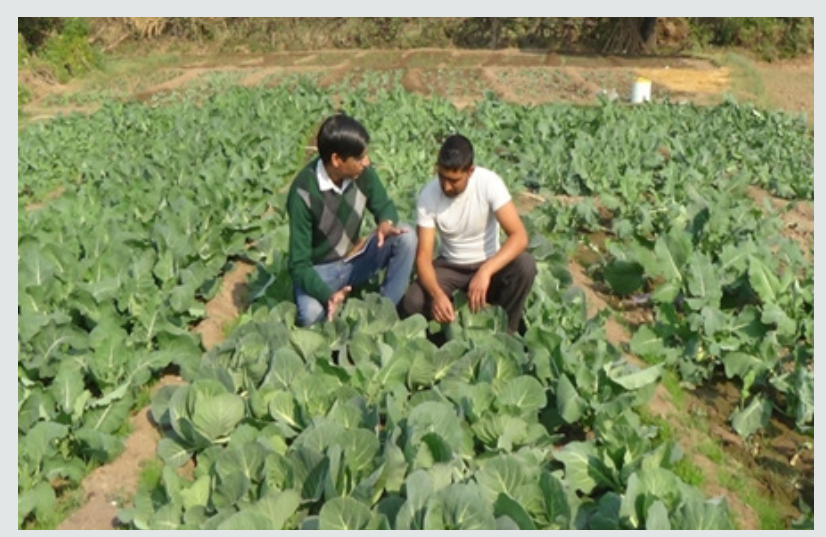

Figure 2: KVK scientist monitoring the organic vegetables at Organic Village Talwara. 


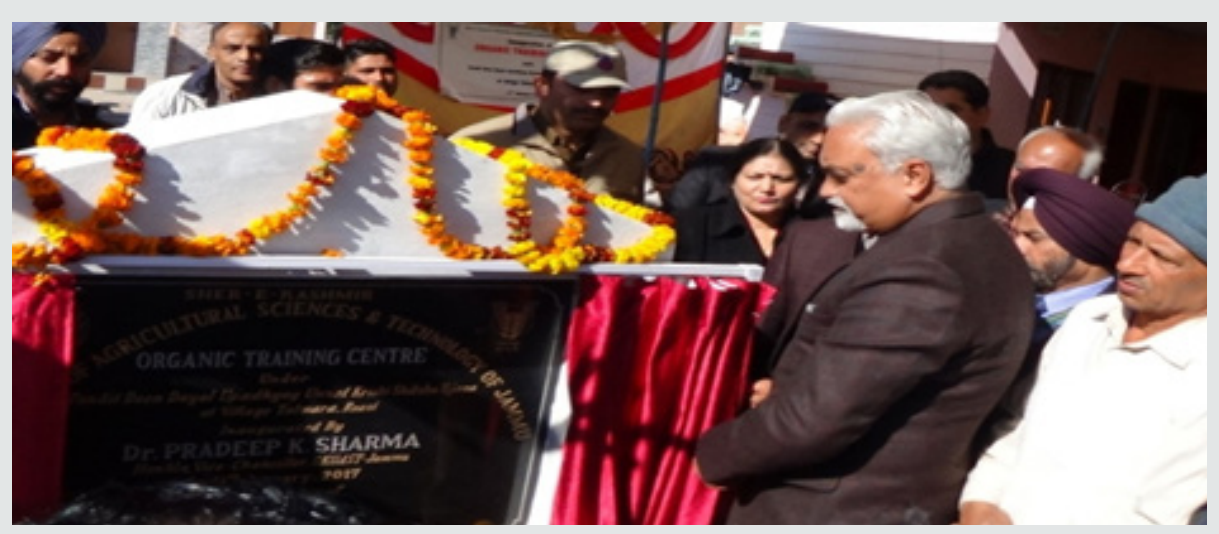

Figure 3:Hon'ble Vice Chancellor of SKUAST-J inaugurating the Organic Training Centre at Talwara.

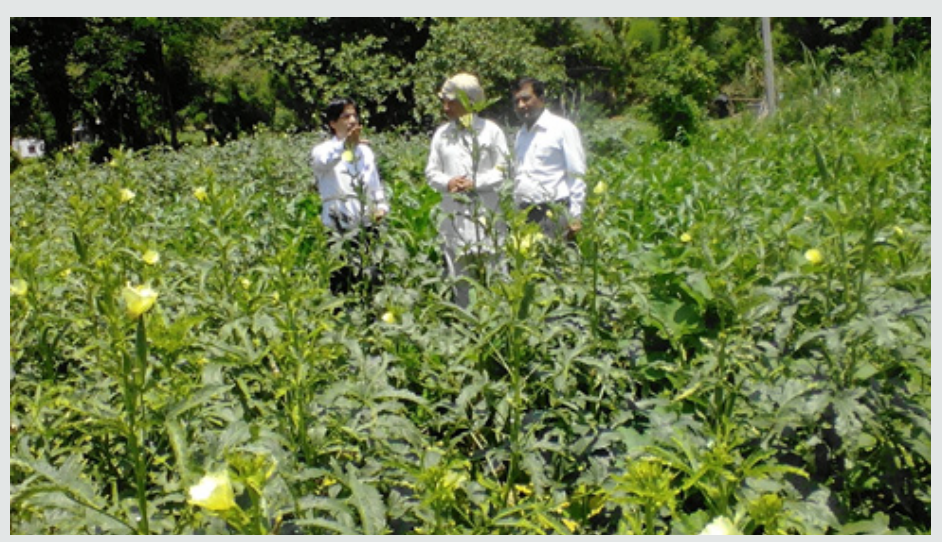

Figure 4:PPV\&FRA Dr.Hanchinal observing organic vegetables at Organic Village Talwara.
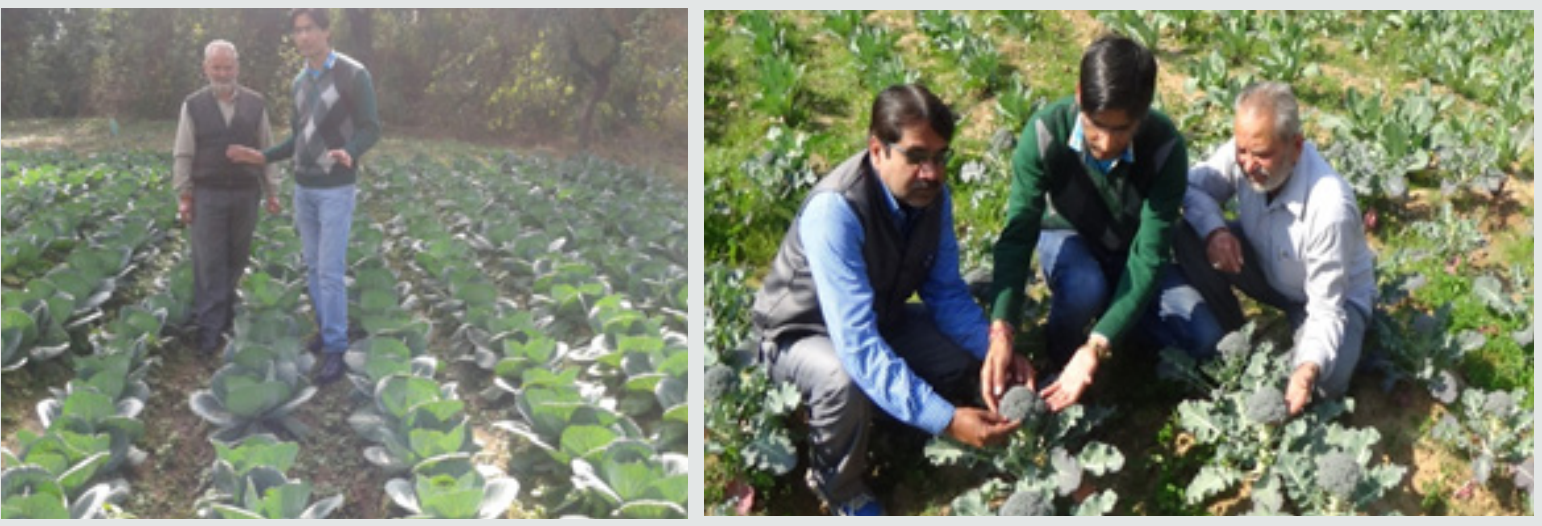

Figure 5:KVK Scientists observing organic produce. 
(c) (i)

This work is licensed under Creative

Commons Attribution 4.0 License

To Submit Your Article Click Here: Submit Article

DOI: 10.32474/CIACR.2019.07.000265

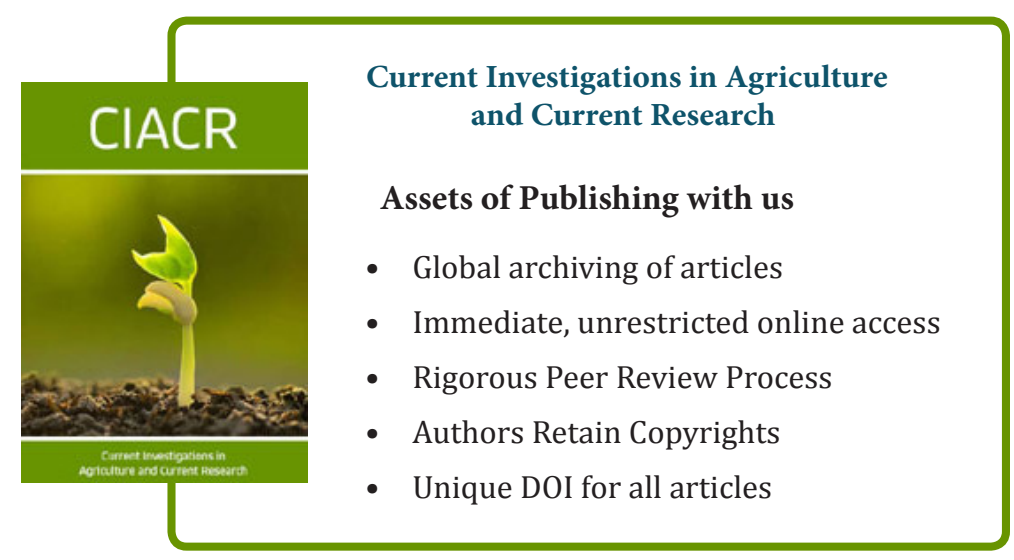

